\title{
The Measurement Levels of Financial Literacy among Postgraduate Management Students: An Empirical Study in Andhra Pradesh State
}

\author{
M. Bala Swamy', Dr. R. Priya ${ }^{2}$ \\ ${ }^{1}$ Research Scholar, Dept of Management Studies, Thanthai Hons Roever College, Perambalur, Tamilnadu. \\ ${ }^{2}$ Head and Asst. Professor, Dept of Management Studies, Thanthai Hons Roever College, Perambalur,
}

Tamilnadu.

\begin{abstract}
Financial literacy is essential to enable students manage their finances and take advantage of investment opportunities. It is against this background that this study investigates financial literacy of Postgraduate management students in the region of Jawaharlal Nehru Technological University, Kakinada (JNTUK), in Andhra Pradesh. It employs a stratified random sampling technique to sample 203 Postgraduate students using questionnaire as the research instrument. This study reveals that formal education is the main source of financial literacy of Postgraduate students, followed by parents, the media, and peers. Level 400 students are the most literate financially followed by level 300, 100 and 200 students. Also, financial literacy is highest among accounting students followed by banking and finance, marketing, and human resource management students.
\end{abstract}

Key words: Financial literacy; Postgraduate students, Bank finance, Financial knowledge, Financial behavior.

\section{Introduction}

Individuals, families, organizations and even countries meet financial challenges one way or another. Financial planning and management in the area of cash management is essential to the success or failure of individuals in achieving their ambitions in life. Financial literacy was defined by Noctor et al. (1992) as 'the ability to make informed judgments and to take effective decisions regarding the use and management of money'. Schagen and Lines (1996) operationalized this definition by proposing that a financially-literate person would enjoy a range of abilities and attitudes comprising: an understanding of the key concepts central to money management; a working knowledge of financial institutions, systems and services; a range of analytical and synthetically skills, both general and specific and; attitudes which allow effective and responsible management of financial affairs.

In spite of this definition and skills required, financial literacy commentators during the last decade have warned of insufficient personal financial literacy. Having financial skills has become more significant as financial markets have been deregulated and credit has become easier to attain because financial institutions compete powerfully with each other for market share. in addition, the progress and marketing of financial products has increased rapidly. People have been encouraged to invest directly by means of the internet and discussion of financial strategies has become part of everyday conversation (Beal et al.2003).

In our educational institutions, topics on personal finance are still considered minimal. If there are programs or activities on it, they are never addressed directly to young consumers especially those between ages 19 to 25 years (Ibrahim et al.2009). Symptoms of insufficient personal financial literacy among students include using personal loans for irresponsible spending or overspending on consumables, irrational commitment to getrich quick schemes among young people, making high-risk investments inconsistent with required capital stability and entering inappropriate vehicle-leasing contracts, among others. Such financial literacy deficiencies can affect an individual's or family's day-to-day financial management and ability to save for long-term goals such as buying a home, seeking higher education, or financing retirement. Ineffective financial management can also result in behaviours that make consumers vulnerable to severe financial crises. There is therefore the need to improve financial literacy of individuals, specifically, students at the university level so they would have positive cash management attitudes before they enter the job market thereby helping them to practice proper personal financial management.

\subsection{Objectives of the Study}

The overall objective is to examine the level of financial literacy among Postgraduate business students in the region of Jawaharlal Nehru Technological University, Kakinada (JNTUK) and establish the relationship between financial knowledge and financial behaviour of Postgraduate business students. 


\section{Literature Review}

The literature review analyses study conducted in the area of financial literacy research. It is divided into two sections: theoretical and empirical.

\subsection{Theoretical Framework}

This section of the literature review elaborates on a theoretical framework used to inform the measurement of financial literacy and behaviour of students. The theoretical construct predominantly used when studying financial decisions and resource management practice is the systems theory (Goldsmith 2005). As indicated by (Goldsmith 2005; Maloch and Deacon (1966) the systems theory is self-reflexive, and is an inputthroughput output- feedback model. This used family resource management theory, based on systems theory, to understand the financial management practices of Postgraduate business students. Deacon and Firebaugh (1981) developed the family resource management theory as a management process with a systems orientation where management is "the process of using resources to achieve goals" (Goldsmith 2005).The four stages in the family resource management model, as developed by Deacon and Firebaugh (1981), explain how people make financial decisions and develop financial behaviours. The stages are inputs, throughputs, outputs, and feedback loop (Figure 2.1). For this study, we only examined the inputs and throughputs sections of the model and added the environmental influences of parents, schools, media and peers (Figure 2.2). The outputs and feedback sections of the model were beyond the scope of this study. To measure outputs and feedback requires longitudinal data, which the researchers did not gather for this study.

Figure 2.1: Family Resource Management Model

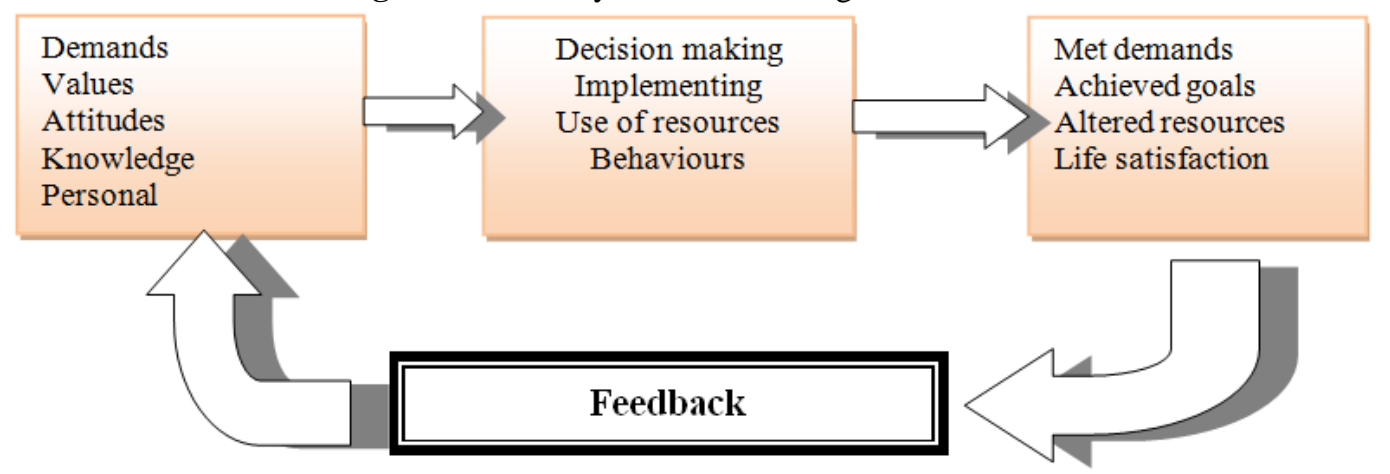

\subsubsection{Environmental Influences}

Social learning theory illustrates how the environmental factors influence university students in shaping them into who they are today. The financial attitudes and values university students have about money come from their environment (Figure 2.1). As students learn over the years through social interaction they begin to understand and form their values, knowledge, and attitudes about finances (Bandura 1977; 1986; John 1999). Family, friends, school, church and media all shape college students' knowledge and attitudes over time (Bubolz and Sontag 1993). This study combines social learning theory and family resource management theory in a way that considers environmental influences that shape where a person currently is with regard to their knowledge, attitudes, and personal characteristics (Figure 2.1).

Figure 2.2: Environmental Factors that Influence Students' Financial Behaviour

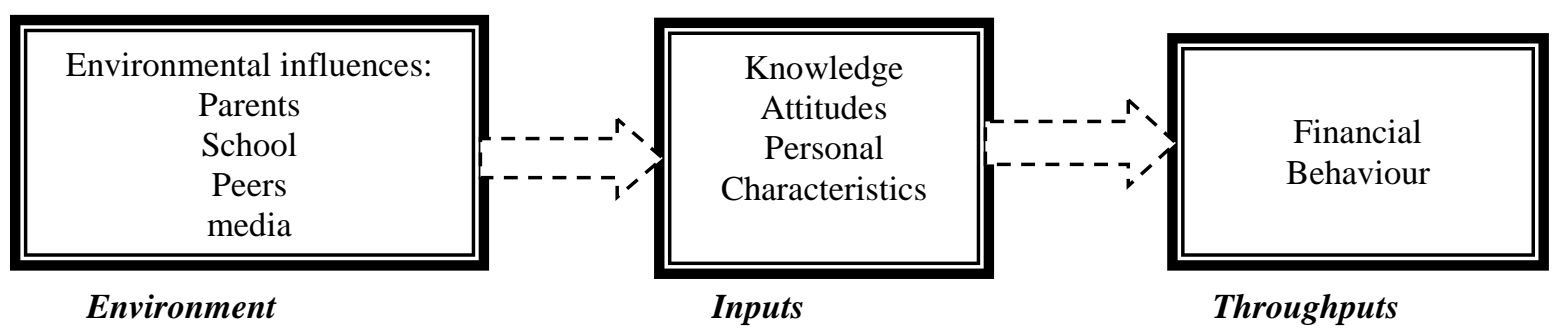

(Source: Goldsmith 2005)

The focus of this study is the personal financial knowledge, attitudes, and behaviours of university Postgraduate business students along with key environmental influences of family, school, peers and the media that help shape students current status. These environmental influences are focused on for this study because of the great influence they have on students' personal financial knowledge, attitudes, and behaviours (Alhabeeb 
1999, John 1999). Parents tend to have a greater influence on students at a younger age (Brown et al. 1993, Clark et al. 2005) while peer influence increases as the student becomes older and especially after becoming a university student (Harris 1995, John 1999). The addition of these environmental influences to our understanding of university students' financial knowledge, attitudes, and behaviour is a major contribution of this study.

\subsubsection{Inputs}

Inputs, the first stage of the family resource management model (Figure 2.1), are the resources and demands the individual has at any given time (Goldsmith 2005, Hayhoe et al. 2005, Rice and Tucker 1986). The resources students have developed come through their interaction with the environment and are the means to satisfy the demands.

\subsubsection{Throughputs}

The throughput section is the second stage of the model and is where decisions are made based on the individual's demands and available resources.

\subsubsection{Outputs}

The third stage is output. Outputs are whether the desired goal was reached or whether demands were met. They are the realized end result that comes based on the decisions made by the individual. Outputs include met demands, achieved goals, altered resources, and level of life satisfaction.

\subsubsection{Feedback}

The fourth stage is the feedback loop. Feedback is continuously used in all stages of the resource management system (Rice and Tucker, 1986). Feedback happens when there is disequilibrium in the individual's life (Goldsmith 2005, Hayhoe et al. 2005). This could be due to having demands not met or goals not achieved. Positive or negative feedback informs input by means of increased knowledge or changed attitude. The new resources available allow the process to happen again as the individual uses new resources to again implement and make decisions in the expectation of a better output that will return equilibrium, which comes from a changed system and satisfaction with the output (Goldsmith 2005). This study combines social learning theory with the theoretical framework of family resource management.

The study uses a survey to measure environmental influences, personal characteristics, financial knowledge, financial attitudes, and financial behaviour. According to family resource management theory, students' financial behaviour is influenced by their demands and available resources (i.e., values, attitudes, knowledge, and personal characteristics). Social learning theory explains that available resources increase from learning developmentally through interaction with the environment (Bandura 1977), which have been identified as parental and peer influences. For behavioural change to take place and be significant, knowledge and attitudes must change (Hayhoe et al. 2005, Miller and C'de Baca 2001).

\subsection{Benefits of Financial Literacy}

Research has shown that financial literacy is beneficial to individuals and families (Blalock et al. 2004, Danes and Hira, 1987, Grable and Joo, 1998, Hibbert and Beutler, 2001, Kerkmanneiet al., 2000). It increases students' chances for saving and investing, getting out of debt, spending less than they earn, and living on a budget. It also decreases their chances for bankruptcy, receiving government assistance (Bauer et al. 2000, Blalock et al. 2004, Huston et al. 2003), and making poor consumer decisions (Grable and Joo 1998, Hayhoe et al. 2000). Students who lack financial knowledge have increased financial difficulties that continue into later years (Danes and Hira 1987, Hibbert and Beutler 2001, Hira 2002). Chen and Volpe (1998) find that students with less financial knowledge have more negative opinions about finances and make more incorrect financial decisions. They point out that having a low level of financial knowledge limits students' ability to make informed decisions.

Danes and Hira (1987) relate students' financial behaviour to their future earning capacity. Danes (1994) mentions that a higher level of financial education influences financial knowledge, attitudes, and behaviours. Financial education increases financial knowledge and affects financial attitudes (DeVaney et al. 1996, Grable and Joo 1998). Increased financial knowledge is also found to influence students' attitudes positively towards business in general and their ability to be wise consumers in society (Langrehr 1979). Lyons and Hunt (2003) find that university students want to receive financial information and have a preference about how financial education is taught, who teaches it, and what the content is.

Also, although perceived economic well-being may differ by gender (Leach et al. 1999), Grable and Joo (1998) find that financial education "levels the playing field" with regard to gender differences and "is effective in changing knowledge, attitudes, and behaviours". Moreover, increasing financial literacy is a way to increase empowerment and improve the quality of life (Knapp 1991, Voydanoff 1990). Energy, thought, and time are spent pursuing money and limiting the unnecessary waste of money. Thus, when students gain more knowledge and more positive attitudes toward money, they make better decisions, which save resources and improve their situation (Knapp 1991). 
Financial literacy also promotes self-confidence, control, and independence (Allen et al. 2007, Conger et al. 1999). This comes by feeling in control and knowing how to function in a complex market place. When consumers feel they are in control of their finances, they are more likely to participate in the market place (Knapp 1991). Norvilitis et al. (2003) find that perceived financial well-being in college students appears to be related to psychological well-being, an ability to be more in control of their lives, and having lower levels of dysfunctional attributes.

Financial literacy goes beyond knowledge about money; it includes being a wise consumer of foods (increasing one's health) and other purchases such as cars (affecting their safety and the environment (Knapp 1991). Thus, increasing financial literacy can affect students' physical health and safety as well as their psychological wellbeing. The financial literacy of students can also affect their current and future family relationships. Hibbert and Beutler (2001) find that families who spend less than they earn, pay bills on time, and avoid unnecessary debt have fewer family tensions and an increased sense of self-worth compared to families who are poor managers of their finances. Students' sense of control and self-mastery are also lower when they experience economic distress (Conger et al. 1999). Thus, as financial literacy increases, quality of life should improve.

Another benefit of increased financial literacy is an increase in marital satisfaction. Kerkmann $e t a l$. (2000) find that behaviours and perceptions of finances as well as problems and their perceived magnitude were significantly related to marital satisfaction. Some have suggested that financial problems are one of the leading causes of marital conflict and divorce (Amato and Rogers 1997). Oggins (2003) reveals that in early years of marriage, the top reason for marital disagreement was finances. Conger et al. (1990) also find that economic difficulties affect family relationships through increased hostility in marital interactions while limiting warm and supportive behaviours expressed by the couple. Financial behaviours are important in marriage because good financial behaviours such as budgeting, paying down debt, saving, and spending less than one earns increase marital satisfaction more than just what one earns (Kerkmann et al. 2000). The financial habits students have while in the university tend to carry on into adult life. The better their financial literacy is when they leave the university, the fewer financial hardships they may have in life (Grable and Joo 1998).

\subsection{Empirical Review}

\subsubsection{Financial Literacy among Students}

Hartford Financial Services Group (2007) finds that a majority are concerned about meeting their financial obligations and felt unprepared to meet future financial challenges. Helman and Paladino (2004) suggest that following graduation, college students realize that they are earning on a constant basis and prefer to spend rather than save. A National Council on Economic Education study (2005) find that 53 per cent of students entering college fail a basic quiz on economics and personal finance in the United States. Avard et al. (2005) examine college freshmen's basic knowledge of financial issues and conclude that recent high school graduates lack an understanding of everyday financial matters. More importantly, a study by James et al. (2002) finds that a lack of financial understanding occurs even when college students have taken business courses stressing the significance of managing and maximizing other peoples' wealth.

Schagen and Lines (1996) identify students in higher education and not living at home as one of the groups susceptible to difficulties with debt and were least confident in dealing with financial affairs. Chen and Volpe (1998) analyse personal finance literacy among 924 students in 14 colleges. Their conclusion was that knowledge of personal finance among US college students was generally poor with the overall mean correct answer score of 53\% and none of the mean scores for general financial knowledge, saving, borrowing, insurance or investments was above $65 \%$. Mae (2009) reveals the need to provide Postgraduate students with education on personal financial management.

Understanding financial literacy among young people is thus of critical importance for policymakers in several areas; it can aid those who wish to devise effective financial education programs targeted at young people as well as those writing legislation to protect younger consumers.

\subsubsection{Implications for Financial Behaviour}

Previous research has also found that financial literacy can have important implications for financial behaviour. People with low financial literacy are more likely to have problems with debt (Lusardi and Tufano 2009), less likely to participate in the stock market (Van Rooij et al. 2007), less likely to choose mutual funds with lower fees (Hastings and Tejeda-Ashton 2008), less likely to accumulate wealth and manage wealth effectively (Hilgert 2003, Stango and Zinman 2007) and less likely to plan for retirement (Lusardi and Mitchell, 2007). Chen and Volpe (1998) reveal that students with less financial knowledge have more negative opinions about finances and make more incorrect financial decisions. Davidson (2006) therefore reveal the need to provide comprehensive training on financial matters to students from high schools, colleges and universities 


\subsection{Gaps in the Financial Literacy Research}

In Andhra Pradesh, less than 20\% of all households have access to financial services (Gyabaah, 2009). Chowa et al (2010) reveal a very low level of financial knowledge among the youth in Andhra Pradesh. USAID (2009) also finds a low national mean of $44 \%$ in terms of financial literacy among Andhra Pradesh. However, a specific study on financial literacy among Postgraduate students is missing.

\section{Research Methodology}

This section discusses and justifies the data collection processes, collection techniques and research design adopted in this study. Also, tools and techniques used for analyzing the data in the study are dealt with in this section.

\subsection{Population}

The study was conducted among Postgraduate Management students of JNTUK, in the region of Krishna district in 2016-17 academic year. The Postgraduate student population was more than 1,200. In this population, here considered convenience sampling as broken down according to the levels of the students, is shown below.

\begin{tabular}{|c|c|c|}
\hline Level & Population & Percentage \\
\hline L100 & 265 & 22 \\
\hline L200 & 292 & 24 \\
\hline L300 & 371 & 31 \\
\hline L400 & 272 & 23 \\
\hline Total & $\mathbf{1 2 0 0}$ & $\mathbf{1 0 0}$ \\
\hline
\end{tabular}

(Source: Student Data Management System, 2016).

\subsection{Sample Size}

In determining the sample size for this study, the following formula was adopted from (deVaus2002), Surveys in Social Research with the following assumptions; 95\% confidence level, 5\% margin of error and estimated heterogeneity of the population to be $20 \%$.

$\mathrm{n}=\mathrm{p} \% * \mathrm{q} \% *[\mathrm{z} / \mathrm{e} \%]^{2}$

Where $\mathrm{n}$ is the minimum sample size required

$\mathrm{p} \%$ is the proportion belonging to the special category

$\mathrm{q} \%$ is the proportion not belonging to the special category

$\mathrm{z}$ is the $\mathrm{z}$ value belonging to the level of the confidence level required, and

$\mathrm{e} \%$ is the margin of error.

$\mathrm{n}=0.20 * 0.80 *[1.96 / 0.05]^{2}$

$\mathrm{n}=245$

Based on the minimum sample size of 245 , the adjusted sample size can be obtained as

$\mathrm{n}^{`}=\mathrm{n} /\{1+(\mathrm{n} / \mathrm{N})\}$

Where; $\mathrm{n}^{`}$ is the adjusted sample size, $\mathrm{n}$ is the minimum sample size and $\mathrm{N}$ is the total population. $\mathrm{n}^{`}=$ $245 / 1+[245 / 1,200]=203$

The adjusted sample size of 203 students representing about $17 \%$ of the total population was considered as the sample size. This gives a sampling fraction of 1:6. That is to say, on the average 6 units of the population was represented by one unit in the sample. The sample size was considered to enable the researchers collect more detailed information on the subject.

\subsection{Sampling Technique and Survey instrument}

The study employed stratified random sampling method in selecting the 203 Postgraduate's students from all levels. The researcher divided the population into four strata that is according to levels (level 100, 200, 300 and 400). From there 28, 54, 71, and 50 were selected from each stratum respectively at random. This gave an equal opportunity and fairness to students at all levels to participant in the survey. A structured questionnaire was used to obtain data from the respondents.

\subsection{Testing for financial literacy}

In testing for financial literacy the study relied on a set of questions developed by jumpstart (www.jumpstart.com) and the results were used to determine the level of financial literacy of the respondents. The questions were based on financial knowledge of interest on savings and borrowings, returns on investments and diversification, insurance cover and time value of money 


\subsection{Characteristics of the Sample}

\section{Discussion}

The survey questionnaire was administered to 203 Postgraduates' students. All students administered with the questionnaire responded to it. The demographic characteristics of the sample are summarized in the Table 4.1 below.

Table 4.1: Demographic Characteristics of the Sample ( $\mathrm{N}=203)$

\begin{tabular}{|llcc|}
\hline & Characteristics & n & \% \\
\hline Gender & Male & 119 & 59 \\
& Female & 84 & 41 \\
& & & 30 \\
& $18-22$ & 61 & 59 \\
Specialization & $23-29$ & 120 & 11 \\
& $30-35$ & 22 & 36 \\
& Accounting & & 33 \\
& Marketing & 73 & 19 \\
& Banking and Finance & 67 & 12 \\
& HRM & 39 & 16 \\
& 100 & 24 & 24 \\
& 200 & & 37 \\
& 300 & 32 & 23 \\
\hline
\end{tabular}

(Source: Primary data 2016)

These demographic characteristics provide a better representation of the sample. The results indicate that majority of the students fall within the age group of 23 and 29. This is an active age group where most major decisions concerning the future of any individual are taken.

4.2 Environmental influences on level of personal financial knowledge among Postgraduate students at JNTUK

The model of the study provides four major environmental influences or sources of financial knowledge among the students. The responses are presented in Table 4.2 below.

Table 4.2 Responses on Environmental Influences on Financial Knowledge

\begin{tabular}{|l|c|c|c|c|c|}
\hline \multicolumn{1}{|c|}{ Environment Influences } & $\begin{array}{c}\text { A lot } \\
\text { (i) }\end{array}$ & $\begin{array}{c}\text { Some } \\
\text { (ii) }\end{array}$ & $\begin{array}{c}\text { Not Match } \\
\text { (iii) }\end{array}$ & $\begin{array}{c}\text { None } \\
\text { (iv) }\end{array}$ & N \\
\hline Family & 48 & 73 & 60 & 22 & 203 \\
& $24 \%$ & $36 \%$ & $39 \%$ & $11 \%$ & 203 \\
\hline School & 87 & 52 & 43 & 21 & $10 \%$ \\
\hline Peers & $43 \%$ & $26 \%$ & $21 \%$ & 20 & 203 \\
& 26 & 84 & 73 & $36 \%$ & 203 \\
\hline
\end{tabular}

(Source: Primary data 2016)

The study examines the opinions of the students on the four major sources of financial knowledge. These were School (formal education), family (parents), peers and the media. In considering the family as source of financial knowledge, $60 \%$ ( $\mathrm{n}=121$ students) confirmed getting financial education from this source (scores 1 and 2 on the scale). $29 \%$ of the respondents $(\mathrm{n}=60)$ confirmed not getting much education from their families and $11 \%(n=22)$ have had no financial education from their families. In terms of school (formal education) as a source of financial literacy, $68 \%$ of the respondents $(\mathrm{n}=139)$ identified school as a primary source of financial literacy. $21 \%$ of the respondents did not see much information coming school and $10 \%$ thought they have had no financial education from school. Another important source of financial literacy that this study sought the views of the respondents on was peers. 54\% $(n=110)$ identified their peers as a prime source of financial literacy. The remaining $46 \%(\mathrm{n}=93)$ did not see peers as a source of financial literacy. Finally, the media is critical in passing on financial education. In this study $32.5 \%(\mathrm{n}=66)$ maintained that the media was key in obtaining financial literacy. The remaining $67.5 \%(n=137)$ discounted the media as source of financial literacy. The results show that formal education (school) is the most prominent source of financial literacy, followed parents (family), the media, and peers as study focused on scores 1 and 2 according to Table 4.2. 


\subsection{Differences in financial knowledge among Postgraduate business students based on gender, level and programme option at JNTUK}

The study used a set of questions to test for financial knowledge on interest on savings and borrowings, returns on investments and diversification, insurance cover and time value of money. A cross-tabulation of the results, based on gender, level and programme option, is presented in tables 4.3, 4.4 and 4.5 below.

Table 4.3: Cross-tabulation of Gender and Level of Financial Literacy

\begin{tabular}{|l|l|l|l|l|l|}
\hline \multicolumn{2}{|c|}{} & \multicolumn{2}{|c|}{ Knowledge test on Financial Literacy } & \multirow{2}{*}{ Total } \\
\cline { 3 - 5 } \multicolumn{2}{c|}{} & $\begin{array}{l}\text { Correct answers to some } \\
\text { questions }\end{array}$ & $\begin{array}{l}\text { Correct answers to all } \\
\text { questions }\end{array}$ & \\
\hline Gender & Male & $\begin{array}{l}\text { Count (n) } \\
\text { \% within Gender }\end{array}$ & 13 & 106 & 119 \\
& & $10.9 \%$ & $89.1 \%$ & $100.0 \%$ \\
\hline \multirow{2}{*}{ Total } & Female & Count (n) & 37 & 47 & 84 \\
& & $\%$ within Gender & $44.05 \%$ & $55.95 \%$ & $100.0 \%$ \\
\hline & Count (n) & 50 & 753 & 203 \\
\end{tabular}

(Source: Field Study 2016)

A cross-tabulation between demographic factor of gender and financial knowledge score was performed and the results reveal $89.1 \%$ of males who took part in the survey were knowledgeable on financial issues while $10.9 \%$ had low financial knowledge. In the same direction, 55.95\% of females who took part in the survey were equally knowledgeable on financial issues while $44.05 \%$ had low financial knowledge (Table 4.4). These results were obtained based on a set on of the survey questionnaire that provided basic test aimed at assessing their levels of financial literacy.

From the performance indicated above, both males and females had equal competitive performance in the financial knowledge test. This further indicates that, there is no significant association between gender and level of financial literacy among Postgraduate business students who took part in the survey. This might be due to the fact that all participants are business students and have equal exposure to one of key environmental influences on financial literacy, which formal education.

Table 4.4: Cross Tabulation of Levels of Students and their Levels of Financial Literacy

\begin{tabular}{|c|c|c|c|c|c|}
\hline & & & \multicolumn{2}{|c|}{ Knowledge test on Financial Literacy } & \multirow[t]{2}{*}{ Total } \\
\hline & & & $\begin{array}{l}\text { Correct answers to some } \\
\text { questions }\end{array}$ & $\begin{array}{l}\text { Correct answers to all } \\
\text { questions }\end{array}$ & \\
\hline \multirow[t]{4}{*}{ Level } & Level 100 & $\begin{array}{l}\text { Count } \\
\% \text { within level }\end{array}$ & $\begin{array}{l}7 \\
21.9 \% \\
\end{array}$ & $\begin{array}{l}25 \\
78.1 \%\end{array}$ & $\begin{array}{l}32 \\
100.0 \%\end{array}$ \\
\hline & Level 200 & $\begin{array}{l}\text { Count } \\
\% \text { within level }\end{array}$ & $\begin{array}{l}14 \\
28.57 \%\end{array}$ & $\begin{array}{l}35 \\
71.43 \%\end{array}$ & $\begin{array}{l}49 \\
100.0 \%\end{array}$ \\
\hline & Level 300 & $\begin{array}{l}\text { Count } \\
\% \text { within level }\end{array}$ & $\begin{array}{l}17 \\
22.67 \%\end{array}$ & $\begin{array}{l}58 \\
77.33 \%\end{array}$ & $\begin{array}{l}75 \\
100.0 \%\end{array}$ \\
\hline & Level 400 & $\begin{array}{l}\text { Count } \\
\% \text { within level }\end{array}$ & $\begin{array}{l}7 \\
14.9 \%\end{array}$ & $\begin{array}{l}40 \\
85.1 \%\end{array}$ & $\begin{array}{l}47 \\
100.0 \% \\
\end{array}$ \\
\hline Total & & $\begin{array}{l}\text { Count } \\
\% \text { within level }\end{array}$ & $\begin{array}{l}45 \\
22.17 \%\end{array}$ & $\begin{array}{l}158 \\
77.83 \%\end{array}$ & $\begin{array}{l}203 \\
100.0 \%\end{array}$ \\
\hline
\end{tabular}

(Source: primary data 2016)

A cross-tabulation between the levels of the students and their level of financial knowledge was also performed. The results reveal that $78.1 \%$ of level 100 students answered all the questions on financial literacy correctly and $21.9 \%$ were unable to answer all the questions correctly. About $71 \%$ of level 200 students answered all the questions correctly and $29 \%$ could not. Also, $77 \%$ of level 300 students who took part in the survey had all the questions answered correctly while the remaining $23 \%$ could not. Finally, out of the 47 students from level 400 who took part in the survey, 40 of them representing $85 \%$ answered all the questions correctly while only 7 of them representing $15 \%$ could not answer all the questions correctly. The results summarized above indicate further that, majority of Postgraduate business students from all levels have high knowledge on financial issues. Notwithstanding performances being higher in levels 400 and 300, there is no significant association between level of programme of study and financial literacy. This might be due to the fact that the respondents are exposed to basic financial issues in the early stages of their study. 
The Measurement of Levels of Financial Literacy among Postgraduate Management Students: An

Table 4.5: Cross Tabulation of Programme (Option) and Levels on Financial Literacy

\begin{tabular}{|c|c|c|c|c|c|c|}
\hline Knowledge test & & \multicolumn{4}{|c|}{ Programme Option } & \multirow[t]{2}{*}{ Total } \\
\hline & & Accounting & Marketing & $\begin{array}{l}\text { Banking and } \\
\text { Finance }\end{array}$ & $\begin{array}{c}\text { Human Resource } \\
\text { Management }\end{array}$ & \\
\hline Incorrect answers & $\begin{array}{l}\text { Count }(\mathrm{n}) \\
\% \text { within Program of study }\end{array}$ & $\begin{array}{l}5 \\
6.85 \%\end{array}$ & $\begin{array}{l}15 \\
22.39 \%\end{array}$ & $\begin{array}{l}12 \\
30.77 \%\end{array}$ & $\begin{array}{l}10 \\
41.67 \%\end{array}$ & $\begin{array}{l}42 \\
20.69 \%\end{array}$ \\
\hline Correct answers & $\begin{array}{l}\text { Count }(\mathrm{n}) \\
\% \text { within Program of study }\end{array}$ & $\begin{array}{l}68 \\
93.15 \%\end{array}$ & $\begin{array}{l}52 \\
77.61 \%\end{array}$ & $\begin{array}{l}27 \\
69.23 \%\end{array}$ & $\begin{array}{l}14 \\
58.33 \%\end{array}$ & $\begin{array}{l}161 \\
79.31 \%\end{array}$ \\
\hline Total & $\begin{array}{l}\text { Count (n) } \\
\% \text { within Program of study }\end{array}$ & $\begin{array}{l}73 \\
100.0 \%\end{array}$ & $\begin{array}{l}67 \\
100.0 \%\end{array}$ & $\begin{array}{l}39 \\
100.0 \%\end{array}$ & $\begin{array}{l}24 \\
100.0 \%\end{array}$ & $\begin{array}{l}203 \\
100.0 \%\end{array}$ \\
\hline
\end{tabular}

(Source: Primary data 2016)

Table 4.5 provides a summary of the performance of business students in the assessment of financial literacy based on programme. Seventy Three (73) students majoring in Accounting were selected for this survey. Out of this, 93.15\%, $(n=68)$ answered all the numerical test questions on financial literacy correctly. $6.85 \%$ $(n=5)$ of the respondents could not answer all the questions correctly. Sixty-seven (67) students majoring in Marketing took part in the survey. $77.61 \%(\mathrm{n}=52)$ answered every question correctly and $22.39 \%(\mathrm{n}=15)$ could not answer all the questions correctly. Thirty-nine (39) students majoring in Banking and Finance took part in the survey. Out of this number, $69.23 \%,(n=27)$ were able to answer all the financial literacy questions correctly and the remaining $30.77 \%(n=12)$ could not answer all the questions correctly. Twenty-four (24) students offering Human Resource Management also took part in the survey. 58.33\% $(\mathrm{n}=14)$ of the respondents answered all the questions correctly and 41.67\%, $(n=10)$, could not solve all the problems correctly. In all, 79.3\%, $(\mathrm{n}=161)$, of all the respondents who took part in the survey answered the test on financial literacy correctly and 20.7\%, $(n=42)$ answered some questions wrongly. These results indicate that, the level of financial literacy among the Postgraduate business students at JNTUK is high. However, the higher scores among the accounting, banking and finance students can be attributed to the fact that they usually study a lot of finance and investment courses which are key sources of financial knowledge.

\subsection{Relationship between financial literacy and financial behaviour of Postgraduate business students at JNTUK}

The study attempted to establish the relationship between financial knowledge and its application in these four basic areas; savings, investments in securities, insurance cover and borrowings. Pearson correlations were used to establish the relationship between these two sets of variables and the results are shown below.

\subsection{Relationship between knowledge about savings and actual savings}

Table 4.6: The Pearson Correlation between Knowledge about saving and spending less than your income

\begin{tabular}{|l|l|r|r|}
\hline & & Knowledge of Savings & Actual Savings \\
\hline Knowledge about & Pearson Correlation & 1 & $.146^{*}$ \\
Savings & sig. (2-tailed) & 203 & .038 \\
& $\mathrm{~N}$ & $.146^{*}$ & 203 \\
\hline Actual Savings & Pearson Correlation & .038 & 1 \\
& Sig.(2-tailed) & 203 & 203 \\
\hline
\end{tabular}

*.correlation is significant at the 0.05 level (2-tailed) (Source: primary data 2016)

From Table 4.6, the coefficient of correlation between knowledge of savings and actual savings is positive (0.146), which means that, as a participant's knowledge of savings is high spending less than their income will also be high. The p-value of (0.038) is less than 0.05 level of significant; hence the relationship between knowledge about savings and spending less than your income is statistically significant.

4.6 Relationship between knowledge about investment in securities and planning and implementing adequate investment programme.

Table 4.7: The Pearson Correlation between knowledge of investment in securities and Planning and implementing a regular investment.

\begin{tabular}{|l|l|lr|r|}
\hline & & $\begin{array}{l}\text { Knowledge of Investment } \\
\text { Securities }\end{array}$ & $\begin{array}{l}\text { Planning and implementing a } \\
\text { regular investment }\end{array}$ \\
\hline $\begin{array}{l}\text { Knowledge about in } \\
\text { Investment Securities }\end{array}$ & $\begin{array}{l}\text { Pearson Correlation } \\
\text { sig. (2-tailed) }\end{array}$ & & 1 & \\
& $\mathrm{~N}$ & 203 & .082 \\
.242 \\
Planning and implementing & Pearson Correlation & & .082 & \\
regular investment & Sig.(2-tailed) & $\mathrm{N}$ & .242 & 203 \\
& & & 203 \\
\hline
\end{tabular}

*.Correlation is significant at the 0.05 level (2-tailed). (Source: primary data 2016) 
The Pearson correlation value between knowledge of investment in securities and planning and implementing regular investments is 0.082 (Figure 4.8). Since it is positive, it indicates that if the respondents' knowledge of investments is high, their level of interest in planning and implementing a regular investment will also be high. However, its corresponding p-value is $(0.242)$ which is more than 0.05 level of significant, hence the relationship or correlation is weak.

\subsection{Relationship between knowledge about insurance and maintaining adequate insurance cover.}

Table 4.8: The Pearson Correlation between Knowledge about Insurance and Maintaining Adequate Insurance

\begin{tabular}{|c|c|c|c|}
\hline & & Knowledge of Insurance & $\begin{array}{l}\text { Maintaining adequate } \\
\text { insurance cover }\end{array}$ \\
\hline $\begin{array}{ll}\text { Knowledge } & \text { about } \\
\text { Insurance } & \end{array}$ & $\begin{array}{l}\text { Pearson Correlation } \\
\text { sig. (2-tailed) } \\
\mathrm{N}\end{array}$ & $\begin{array}{r}1 \\
203 \\
\end{array}$ & $\begin{array}{r}.094 \\
.183 \\
203 \\
\end{array}$ \\
\hline $\begin{array}{l}\text { Maintaining adequate } \\
\text { insurance cover }\end{array}$ & $\begin{array}{l}\text { Pearson Correlation } \\
\text { Sig.(2-tailed) } \\
\mathrm{N}\end{array}$ & $\begin{array}{l}.094 \\
.183 \\
203\end{array}$ & $\begin{array}{r}1 \\
203\end{array}$ \\
\hline
\end{tabular}

*. Correlation is significant at the 0.05 level (2-tailed). (Source: primary data 2016)

From Table 4.8 above, the coefficient of correlation between knowledge of insurance and having an insurance cover is positive, (0.094), which means that, as a respondent's knowledge of insurance increases, they will be willing to maintain higher insurance cover over life and property but the correlation is a very weak one. This is further explained by the level of significant, as its p-value of $(0.183)$ is more than the 0.05 level of significance, hence the relationship is not statistically significant.

Relationship between knowledge of borrowing and ability to afford before making a purchase

Table 4.9 : The Pearson Correlation between Knowledge of Borrowing and an Assessment of Affordability before Making a Purchase

\begin{tabular}{|l|l|r|r|}
\hline & & Knowledge of Loans & Ability to afford before making a purchase \\
\hline Ledge on Loans & Pearson Correlation & 1 & $.234^{* *}$ \\
& sig. (2-tailed) & 203 & 0.001 \\
& $\mathrm{~N}$ & $.234^{* *}$ & 203 \\
\hline Ability to afford & Pearson Correlation & 0.001 & 1 \\
before making a & Sig.(2-tailed) & 203 & 203 \\
purchase & $\mathrm{N}$ & & 2 \\
\hline
\end{tabular}

**.Correlation is significant at the 0.01 legel (2-tailed). (Source: primary data 2016)

From table 4.9 the Pearson correlation value between knowledge of loans and the assessment of the ability to afford before making a purchase from one's own income is 0.237 ( $p=0.001$ ), which is positive, indicating that as a respondent's knowledge of taking loans and their future consequences they will be very cautious of the ability to afford before buying. The p-value of $0.001<0.01$ level of significant, indicating statistical significance. This means that, as the respondents' knowledge of taking loans and their future consequences increases they will be very cautious of their ability to afford before buying any item and vice versa, hence the positive relationship.

\subsection{Application of financial knowledge among Post Graduate Business Students at JNTUK}

To detemine whether undergraduate business students at JNTUK apply the financial knowledge and resources gained from the environment in there daily financial decision-making participants were asked if they patraonize financial products or services. The financial products or services include: savings account, current account, investments in financial securities, insurance or loan facililty. The responses received are summarised in fugure 4.1 below:

Figure 4.1: Patronage of Financial Literacy Products

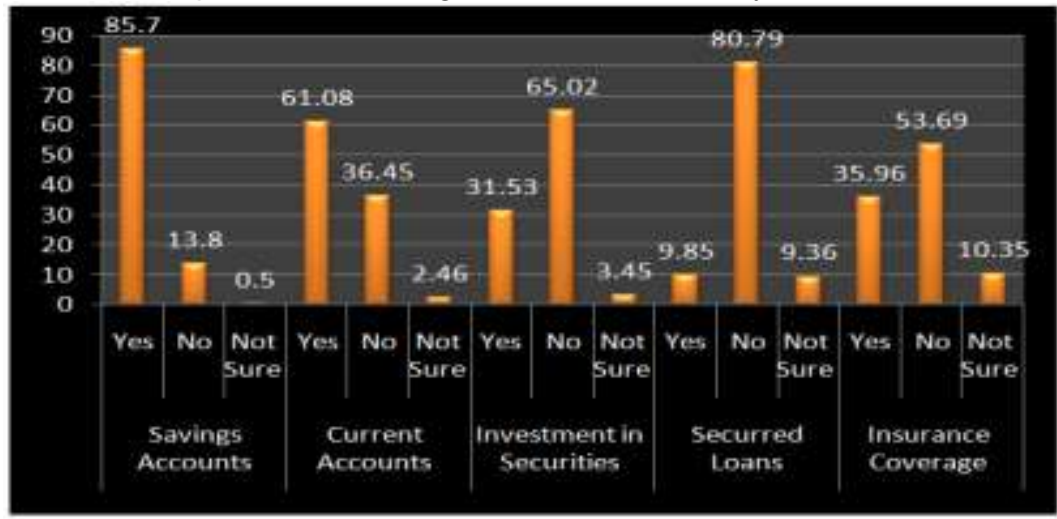


From figure 4.1 above, $85.7 \%,(n=174)$ acknowledged the usage of a savings account with a financial institution while $13.8 \%(\mathrm{n}=28)$ responded 'no'. and $0.5 \%(\mathrm{n}=1)$, were not sure of ever using a savings account. The findings indicates that, majority of participants understand and use savings accounts to monitor their finances as students. $61.08 \%(n=124)$ acknowledged the use of a current account with a bank, 36.45\% $(n=74)$ do not use a current account and $2.46 \%(\mathrm{n}=5)$, were not sure of ever using a current account. This is an indication that more than $50 \%$ appreciates the use of cheques aside cash in financial transactions. When it comes to investments in securities like shares, treasury bills or bonds, 31.53\% ( $n=64)$ acknowledged ever buying a security, $65.02 \%(n=132)$ have never invested their savings in any security before, and $3.45 \%(n=7)$ were not sure of undertaking such investments. This is an indication that majority of participants are unable to put their savings into investments. This might be due to the fact that these students depend on a very meager income. There is not much to save and therefore no need to make savings/investment plans. Further, only $9.85 \%(n=20)$ had ever used a loan facility from a financial institution. Majority of the participants representing $80.79 \%$ $(n=164)$ acknowledged never using a loan facility before and $9.36 \%,(n=19)$ do not have any idea about borrowing. The findings show that majority of participant depend on their own finances and support from their parents instead of borrowing from financial institutions. On the use of insurance, 35.96\% $(n=73)$ of the participants had purchased insurance products. 53.69\% $(\mathrm{n}=109)$ had no form of insurance cover and $10.35 \%$ $(n=21)$ had no idea of ever using an insurance cover before. This indicates the poor attitude of students in insuring against the future. In all, management students are more likely to be knowledgeable in financial issues, have positive attitudes and behaviours. However, putting this knowledge into use on everyday financial decisions making on investments and insurance appear not be encouraging. Factors such as high levels of poverty, inflation and unemployment reduce the excitements of students on the various financial products in the economy.

\section{Conclusion And Policy Implication}

Increasing financial literacy is a way to increase empowerment and improve the quality of life. Energy, thought, and time are spent pursuing money and limiting the unnecessary waste of money. Thus, when students gain more knowledge and more positive attitudes toward money, they make better decisions, which save resources and improve their situation. It is against this background that this study sought to determine the level of financial literacy among Postgraduate students at JNTUK and establish the extent to which they apply the financial knowledge they have. The study reveals a high level of financial literacy among the students even though financial literacy among Andhra Pradesh is low. Furthermore, there is a positive relationship between financial knowledge and financial behaviour among the Postgraduate business students at JNTUK. This is in line with the study by Chen and Volpe (1998), which found that students' positive financial attitudes and behaviours were significantly related to having a higher level of financial knowledge The policy implication of our study is that parents/families have been found to be an important source of financial literacy. Parents could be educated on personal finance through TV programmes, community workshops and seminars. Creating and distributing flyers and information sheets on how and where to obtain more financial knowledge can be considered. The Ministry of Education should also consider introducing personal finance into the core curriculum of secondary and tertiary institutions to improve the level of financial literacy among students.

\section{References}

[1]. Ajzen, I. \& Fishbein, M. (1980), “Understanding Attitudes and Predicting Social Behaviour”, Englewood Cliffs, NJ: Prentice-Hall.

[2]. Alhabeeb, M. J. (1999), "Allowances and the Economic Socialization of Children", Association for Financial Counselling and Planning Education, 10 (2), 1-9.

[3]. Allen, M. W., Edwards, R., Hayhoe, C. R.and Leach, L. (2007), "Imagined interaction, attitudes towards money and credit, and family coalitions", Journal of Family and Economic Issues, 28, 3-22.

[4]. Amato, P. \& Rogers, S. (1997), 'A longitudinal study of marital problems and subsequent divorce', Journal of Marriage and the Family, vol. 59, pp. 612-624.

[5]. Atkinson, A. and Messy, F. (2012), "Measuring Financial Literacy: Results of the OECD / International Network on Financial Education (INFE) Pilot Study", OECD Working Papers on Finance, Insurance and Private Pensions, No. 15, OECD Publishing.

[6]. Avard, S.and Manton,E. (2005), "The Financial Knowledge of College Freshmen", College Student Journal. 39(2), 321339.Bandura, A. (1986), "Social foundations of thought and action: A social cognitive theory", Englewood Cliffs, NJ: PrenticeHall.

[7]. Bandura, A. (1977), "Social learning theory", Englewood Cliffs, NJ: Prentice-Hall.

[8]. Bauer, J. W., Braun, B., and Olson, P. D. (2000), "Welfare to Well-Being Framework for Research, Education, and Outreach", The Journal of Consumer Affairs, Vol. 34(1), 62-81.

[9]. Beal, D.J. and Delpachitra, S. (2003), "Financial literacy among Australian university students", Economic Papers, 22(1), 65-78.

[10]. Blalock, L. L., Tiller, V. R., and Monroe, P. A. (2004), "They Get You Out of Courage: Persistent Deep Poverty among Former Welfare-Reliant Women", Family Relations, 53, 127-137.

[11]. Brown, B. B., Mounts, N., Lamborn, S. D., and Steinberg, L. (1993), "Parenting Practices and Peer Group Affiliation in Adolescence", Child Development, 64, 467-482.

[12]. Bubolz, M. M., and Sontag, M. S. (1993), "Human Ecology Theory: Sourcebook of Family Theories and Method: A Contextual Approach, New York: Plenum, 419-448

[13]. Bird, S. (2008), "Financial literacy among university students: an Australian case study", University of Wollongong. Available at http://ro.uow.edu.au/theses/112 
[14]. Borodich, S., Deplaze, S., Kardash, N., and Kovzik, A. (2010), "Comparative Analysis of the Levels of Financial Literacy among Students in the U.S., Belarus and Japan”, Journal of Economics and Economic Education Research, 11(3), 71 - 83.

[15]. Calamato, M. P. (2010), "Learning Financial Literacy in the Family", Available at http://scholarworks.sjsu.edu/etd theses/3849

[16]. Chen, H., and Volpe, R. P. (1998), “An Analysis of Personal Financial Literacy among College Students", Financial Services Review, 7(2), 107-128.

[17]. Chen, H. and Volpe, R.P. (2002), "Gender Differences in Personal Financial Literacy among College Students", .Financial Services Review, 11, 289-307.

[18]. Clarke, M. D., Heaton, M. B., Israelsen, C. L., and Eggett, D. L. (2005), "The Acquisition of Family Financial Roles and Responsibilities", Family and Consumer Sciences Research Journal, 33, 321-340.

[19]. Cleek, M. \& Pearson, T. (1985), "Perceived cause of divorce: an analysis of interrelationships", Journal of Marriage and the Family, pp. 179-183.

[20]. Conger, R. D., Jewsbury-Conger, K., Matthews, L. S., and Elder, G. H. Jr. (1999), "Pathways of Economic Influence on Adolescent Adjustment", American Journal of Community Psychology, 27, 519-541.

[21]. Danes, S. M. (1994), "Parental Perceptions of Children's Financial Socialization", Financial Counselling and Planning, 5, $127-146$.

[22]. Danes, S. M., and Hira, T. K. (1987), "Money Management Knowledge of College Students", Journal of Student Financial Aid, 17(1), 4-16.

[23]. Deacon, R. E. and Firebaugh, F. M. (1981), "Family Resource Management: Principles and Application", Allyn and Bacon, Inc., Boston, MA Davidson, I. B. (2006), "Financial Literacy Important to Future", Montana Business Quarterly, $44(3), 22$.

[24]. DeVaney, S. A., Gorham, E. E., Bechman, J. C., \& Haldeman, V. A. (1996) Cash flow management and credit use: Effect of a financial information program. Financial Counseling and Planning, 7, 81-80.

[25]. Frederick W. Langrehr (1979), Consumer Education: Does It Change Students' Competencies and Attitudes? Journal of Consumer Affairs 13 (1), 41-53

[26]. Gyabaah, N. (2009), "Andhra Pradesh National Strategy for Financial Literacy and Consumer Protection in the Microfinance Sector", Ministry of Finance and Economic Planning (MoFEB), Accra, Andhra Pradesh.

[27]. Hastings, J. S. and Tejeda-Ashton, L. (2008), Financial Literacy, Information, and Demand Elasticity: Survey and Experimental Evidence from Mexico, NBER Working Paper No. 14538 JEL No. H0,H55,L10

[28]. Harris, J. R. (1995), "Where Is the Child's Environment? A Group Socialization Theory of Development", Psychological Review, $102,458-489$.

[29]. Hayhoe, C. R. (2002), "Comparison of Affective Credit Attitude Scores and Credit Use of College Students at Two Points in Time", Journal of Family and Consumer Sciences: From Research to Practice, 94, 71-77.

[30]. Hayhoe, C. R., Leach, L., Allen, M. W., and Edwards, R. (2005), "Credit Cards Held By College Students", Financial Counselling and Planning, 16 (1), 1-10.

[31]. Helman, R. and Paladino, V. (2004), "Will Americans Ever Become Savers? The 14th Retirement Confidence Survey", Employee Benefit Research Institute Issue 268, 1-17.

[32]. Hilgert, M. A., Hogarth, J. M., \& Beverly S.G. (2003) Household Financial Management: The Connection between Knowledge and Behavior, Federal Reserve Bulletin, 89 (7), 309-322.

[33]. Hira, T. K. (2002), "Current Financial Environment and Financial Practices: Implications For Financial Health", Journal of Family and Consumer Sciences, 94(1), 1-4.

[34]. James, J., Leavel, W. H. and Maniam, B. (2002), "Financial Planning: Managers, and College Students", Managerial Finance, 28(7), 35-43.

[35]. John, D. R. (1999), "Consumer Socialization of Children: A Retrospective Look at Twenty-Five Years of Research", Journal of Consumer Research, (26), 183-213.

[36]. Kerkmann, B. C., Lee, T. R., Lown, J. M., and Allgood, S. M. (2000), "Financial Management, Financial Problems and Marital Satisfaction among Recently Married University Students", Association for Financial Counselling and Planning Education, 11(2), 55-64.

[37]. Knapp, J. P. (1991), “ The benefits of consumer education: A survey report” [Brochure]. Michigan Consumer Education Center

[38]. Kunateh, M.A. Financial Literacy low among Adults in Northern Andhra Pradesh. Andhra Pradeshian Chronicles, 20th August, 2009 , p. 8.

[39]. Leach, L. J., Hayhoe, C. R., and Turner, P. R. (1999), "Factors Affecting Perceived Economic Well-Being of College Students: A Gender Perspective", Financial Counselling and Planning, 10(2), 11-22.

[40]. Lyons, A. C. (2004), “A Profile of Financially At-Risk College Students”, Journal of Consumer Affairs, 38 (1), $56-80$.

[41]. Lusardi, A. and Mitchell, O. S. (2007), "Financial Literacy and Retirement Preparedness: Evidence and Implications for Financial Education Programs", Business Economics, 42(1), 35-44.

[42]. Lusardi, A., Mitchell, O. S. and Curto, V. (2010), "Financial Literacy among the Young", Journal of Consumer Affairs. 44, 358380 .

[43]. Lusardi, Annamaria, and Peter Tufano (2009b), “Teach Workers about the Peril of Debt," Harvard Business Review, November, pp. 22-24.

[44]. Maloch, F., and Deacon, R. E. (1966), "Proposed Framework for Home Management", Journal of Home Economics. pp.31-35.

[45]. Miller, W. R., and Cde Baca, J. (2001), "Quantum change: When Epiphanies and Sudden Insights Transform Ordinary Lives", New York: Guilford Press.

[46]. Noctor, M.,Stoney, S. and Stradling, R. (1992), "Financial Literacy: A report prepared for the National Westminster Bank", London.

[47]. Norvilitis, J. M., Szablicki, P. B., and Wilson, S. D. (2003), "Factors Influencing Levels of Credit card Debt in College Students", Journal of Applied Social Psychology, 33, 935-947.

[48]. Oggins, J. (2003), "Topics of Marital Disagreement among African-American and Euro-American Newlyweds", Psychological Reports. 92, 419-425.

[49]. Rice, A. S. and Tucker, S. M. (1986), "Family Life Management", New York: Macmillan.

[50]. Schagen, S. and Lines, A. (1996), "Financial Literacy in Adult Life: A Report to the NatWest Group Charitable Trust", Slough, Berkshire: National Foundation for Educational Research.

[51]. Yeung, W. J. and Hofferth, S.L. (1998), "Family Adaptions to Income and Job Loss in the United States", Journal of Family and Economic Issues, 19 (3), 255-283.

[52]. Yilmaz, H. (2011), "Improving Financial Literacy: The United States Experience", International Journal of Business and Social Science, 2 (11), $65-72$. 